\title{
A Taxonomy of Metaphorical Labyrinths
}

\begin{abstract}
Ab obscuris ad obscuriora transimus, et cum Moyse ingredimur in nubem et caliginem. Abyssus abyssum invocat, in voce cataractarum Dei, et gyrans gyrando vadit spiritus, et in circulos suos revertitur. Labyrinthios patimur errores, et Christi caeca regimus filo vestigia.
\end{abstract}

We pass from obscurity to greater obscurity, and enter with Moses into cloud and darkness; deep calls to deep at the sound of the cataracts of God, and, circling in circles, the spirit goes forth and returns to its own circuits. We endure labyrinthine errors and guide our blind footsteps by the thread of Christ.

Jerome, Preface to Book 2, Commentary on Zacharias

I

N CHAPTER 1, the literary tradition of the labyrinth defined by Virgil, Ovid, and Pliny suggested the inherent and convertible duality of the maze as monument of admirable artistic complexity and cause of subjective confusion. Chapter 2 approached labyrinthine duality from a complementary perspective, using the conflict between two persistent paradigms, the multicursal maze of literature and the unicursal maze of art, as a means to identify the essential characteristics and formal implications of classical and medieval mazes. These essential characteristics define the maze as a complicated artistic structure with a circuitous and ambiguous design whose confusing toils are intended by their clever architect to entrap or enlighten errant mazewalkers, denying or controlling access to a center that may contain good or evil, and leaving the maze-walker with higher knowledge or in chaotic limbo. Now we move from theory to practice and see how these structural features inform a wide variety of classical and early Christian texts that use the labyrinth metaphorically. As in several later chapters, I present here a fairly comprehensive survey of mazes, partly because literary labyrinths have so seldom been studied in themselves or in rela- 
tion to mazes in the visual arts. My aim is dual: to show how the idea of the labyrinth and its structural features generate metaphor, and to indicate what metaphorical meanings mazes typically attract.

Metaphors rely on analogies between the qualities of a sign and the comparable attributes of what is signified. Metaphorical associations of the labyrinth thus develop naturally from the essential characteristics identified in Chapter 2; indeed, I began to suggest there, in purely abstract terms, how specific formal qualities of the classical-medieval maze imply metaphorical potential, how structure generates possible meaning. Chapter 3 fleshes out that discussion with reference to classical and early Christian texts and derives its taxonomy of metaphorical labyrinths from the form and functions of the labyrinth itself rather than from such extraneous categories as the world as labyrinth or the text as labyrinth. It is true that this taxonomy, like most others, is somewhat arbitrary: if all labyrinths manifest certain essential characteristics simply by virtue of being labyrinths, it may seem artificial to divide maze metaphors according to the prominence of one labyrinthine feature or another, as I do here. In most cases, however, maze metaphors do highlight one characteristic, subordinating the others. When the maze signifies a prison, for example, the metaphor accentuates inextricability even though the cause of that inextricability involves another labyrinthine characteristic, a complexity of structure that may well be artistically admirable in itself. It may help to remember that our perception of labyrinths is tied to point of view, and one property or another predominates according to the beholder's perspective. So too with metaphorical mazes, which of ten presume a particular point of view. Do we see the maze in its entirety-from outside and above, with its structure neatly mapped as in a diagrammatic drawing? Then we see the maze as artifact, and we may be struck most by its admirable albeit complex order. Do we watch as a wanderer becomes increasingly entangled without any guidance? If so, we may be aware chiefly of the maze's inextricability or impenetrability. Do we experience a labyrinth's immediate psychological effect by joining a wanderer within the maze and then emerging into clarity as and when he does? Then the text emphasizes the maze as complex process leading from ignorance to enlightenment.

This chapter is therefore divided into three sections, each roughly corresponding to the essential labyrinthine quality highlighted in metaphor: (a) the labyrinth as a sign of complex artistry; (b) the labyrinth as a sign of inextricability or impenetrability; and (c) the labyrinth as a sign of difficult process. These categories correspond to three of the four primary qualities of the classical-medieval labyrinth as defined in Chapter 2. Examples in each group may allude to the labyrinth's convertibilityto sudden changes in the beholder's perception whereby confusion becomes clarity or vice versa. Each text may draw on other major or minor 
characteristics of the maze, although those other qualities are subordinated to the chief defining feature emphasized by the metaphorist. And each includes, implicitly or explicitly, reference to the maze's fourth essential quality: the structural presence of ambages and circuitousness. I have not used this labyrinthine necessity as the governing principle of a fourth category because it is so much a given in all cases that one cannot base on it meaningful distinctions between metaphors. Ambages are the basic units of which labyrinthine artistic complexity is composed; they render the maze inextricable or impenetrable; they define the difficult process a wanderer undergoes. It is possible to isolate artistry, inextricability and impenetrability, and difficult process as dominant features on which metaphors are based; it is impossible to do so with ambages, the indispensable labyrinthine quality.

\section{- The Labyrinth as a Sign of Complex Artistry •}

Many metaphorical uses of the labyrinth have a major aesthetic component based on the fact that, fully perceived and appreciated, the maze transcends apparent disorder to reveal a grand design. The analogy between the maze and what it signifies rests on the intricate complexity of the signified's structure once it is, perhaps with some difficulty, seen whole as a work of art. Often, as in the texts of Chapter 1, the architect is celebrated as well as his artifact-the creator is praised through the creation that testifies to his skill and fame, for a maze's very complications assert the ordering intelligence of the maze-maker. Thus the labyrinth generally functions in bono as a sign of complex visual or verbal artistry in the classical and early Christian periods (this is not always true in medieval literature); but there may also be degrees of excellent complexity, and human architects and labyrinths are not necessarily the best.

Sometimes the ancient labyrinths, works of men, are compared with the works of animals. Thus Aelian (170-233 A.D.) comments on the protective architecture of the ant: "Historians celebrate the underground passages of the Egyptians; they also with the company of poets celebrate certain labyrinths in Crete. They have yet to learn of the elaborate tracks with their mazy windings dug by ants in the earth. Now in their wisdom these make their underground dwelling so very tortuous as to render access difficult or totally impossible for such creatures as have designs upon them."' The greatest architects, then, are no cleverer than unthinking creatures. Gregory of Nazianzus (330-39o) goes farther,

1. Aelian, On the Characteristics of Animals, trans. A. F. Scholfield, LCL, 3 vols. (Cambridge: Harvard University Press, 1959), 6.43. 
finding the human artistry of labyrinth dances and structures (not to mention labyrinthine reasonings and rhetoric) inf erior to the instinctive, God-given architectonic ability of animals. Stressing the vastness of God and his utter incomprehensibility to human reason, Gregory suggests that we can learn to know at least something of an intrinsically labyrinthine and mysterious God through his magnificent handiwork, both in itself and as manifested through God's creatures, whose architectural skill surpasses ours. Who, Gregory asks, gave the bees their ability to construct their miraculously regular and complex hives? Who taught the spider to make its web, that perf ect trap full of intricate windings? What Euclid could imitate this fine geometry, what Phidias could fashion such beauty? "What harmonious dance of Knossos, Daedalian work, performed by a young girl and reaching the height of beauty? Or what Cretan labyrinth, with the difficult exit and inextricable turnings-to use the poets' word-returning so many times on itself through the artist's craft?" 2 And, he continues, he has said nothing of the treasury of the ants; but if you understand all this, then consider the diversity of plants, of the earth itself!

For the stoic Aelian and the saint as well, the implications are clear: who is man to pride himself on his labyrinthine artistry-who even is the legendary Daedalus-in comparison to the thoughtless animals, whose craft is still greater? And if animal artistry surpasses ours, what of the divine artistry that empowered the animals? For Gregory, God himself is the only true Daedalus, father of architects, and his labyrinthine handiwork is the cosmos. That is what needs, and defies, explication; "search, man, and see if you can follow even one of these paths!" (28.27). God's obscurity, which we can try to penetrate as if it were a labyrinth, is the true and humbling goal of intelligent endeavor, but we are unlikely to succeed. There is perfect order in the divine labyrinth of creation, but the feeble tool of human reason, limited in perspective and nature by its imprisonment within the mundane maze, ill equips us to discover it. To

2. Gregory of Nazianzus, Second Theological Oration 28.25, in Discours 27-31, ed. Paul Gallay and Maurice Jourjon (Paris: Editions du Cerf, 1978). The sequential mention of Ariadne's dance, ultimately derived from the Iliad, and the Cretan labyrinth is suggestive but inconclusive: Are dance and structure linked because of their common creator Daedalus? because one takes place in, or is shaped by, the other? because both derive from the matter of Crete? Neither Gregory nor common sense provides a definitive answer. The whole oration is characterized by labyrinthine language-language ref erring to the following of difficult and obscure paths to reach some goal-which is appropriate, given the subject of the discourse. Whether this Greek text was known in the Latin Middle Ages I do not know; certainly Guibert of Nogent, Thomas Aquinas, and even Ralph Higden cite other works by Gregory. In any case, I am not arguing the direct transmission of this and other Greek texts but wish to suggest instead that one person's way of interpreting the labyrinth might have been duplicated by others independently; the metaphorical potential of the image itself is most important.

For a full discussion of this passage and of the Oration itself, which ends with a quasiDantean ascent above the mundane labyrinth, see Miller, Measures of Wisdom, pp. 345-361. 
us, much is and must remain confusion, enigma, and darkness. We cannot work our way through the labyrinth to see God, or at least not by the exercise of reason.

The work of man earns somewhat greater esteem with Marius Victorinus (fourth century), who explains the origin of the classical ode's strophe, antistrophe, and epode by referring to Theseus's dance at Delos after he conquered the labyrinth. In this ritual-presumably related to Ariadne's Daedalian dancing floor in the Iliad and to the dance mentioned by Gregory-Theseus "imitated the conf used and twisting journey of the labyrinth with the boys and girls who had escaped with him, singing as they danced first in one circuit, then winding back." 3 Victorinus notes that this dance also mimics celestial harmony, so that the first pattern of the dance, moving to the right, imitates the turning of the heavens from east to west; the second, to the left, enacts the orbits of the planets (erratic stars, to use labyrinthine language) from west to east; and in the third movement all stand still like the earth, around which everything else circles. Victorinus thus suggests that labyrinth, cosmos, dance, and (to return to Victorinus's nominal subject) the structure of poetry are all related instances of magnificent but complex design composed of turns and counterturns. Human labyrinths imitate divine cosmic art. We will see in Chapter 5 how Victorinus's comments on the labyrinth dance may inform the fourteenth-century dance at Auxerre Cathedral.

A more difficult and problematic linking of poetry, fame, the labyrinth, and nature comes from Ennodius (fl. 513), bishop of Pavia, wordsmith of "sonorous humanism and unprofitable virtuosity."4 Following a tortuous path through the Alps, he reflects, "Why, fame of the ancient poets, do you entwine labyrinthine recesses with your tongues, which anyone re-reading would fear [or: so as to frighten a reader]? There [as described in poetry] was a laudable wandering made by a craftsman, when Daedalus twisted the straight way with his ingenuity. Here [in the Alps] nature carries man through the clear air." 5 One expects stylistic labyrinths from Ennodius; this textual one seems to associate pagan poetry with mazes, partly in that classical poets wrote about the terrors of the labyrinth. Ars poetriae may thus be ars daedala, a position consistent with Ennodius's own ornate practice. He also seems, like Aelian and Gregory, to be making a point about art vs. nature: labyrinthine poets

3. Marius Victorinus, Ars grammatica, in Grammatici latini, ed. Heinrich Keil, vol. 6 (Hildesheim: Georg Olms Verlagsbuchhandlung, 1961), p. 6o. For Victorinus, a rhetorician and Christian convert mentioned in Augustine's Confessions $(8.3,4)$ and well-known to the Chartrian philosophers, see Pierre Hadot, Marius Victorinus: Recherches sur sa vie et ses oeuvres (Paris: Etudes Augustiniennes, 1971).

4. Pierre de Labriolle, History and Literature of Christianity from Tertullian to Boethius, trans. Herbert Wilson (London, 1924; repr. New York: Barnes \& Noble, 1968), p. 489.

5. Ennodius, Carmina 1.1, $P L, 63,310$. 
are artificers, like Daedalus, however praiseworthy the errores they craft; and their art is inferior to Nature's, whose tortuous path is truly the way to Olympus. God's labyrinth exceeds man's, and the fame of God the creator surpasses that of mere poets, whose paltry pride in their complex workmanship pales in comparison. Probably there are also hints here of a common metaphorical association of the maze we shall examine shortly: pagan learning is a dizzying labyrinth of deception, Christian learning is true order. Daedalus's work, a real building, presumably falls somewhere in between.

As God's labyrinthine structures, whether built by him or his nonhuman creatures, eclipse those of human architects and dancemakers, so too, as Ennodius suggests, with labyrinths of words-poetic or prophetic texts. Human poetry and rhetoric-complex arts moving circuitously from beginning to end-are potentially labyrinthine. Thus Sidonius Apollinaris $(431-487)$ praises one Peter's poetry: "We have the completed work; weaving [texens] it with art in the dimeter, he has run a hard journey and labyrinthine ways." 6 The difficulties of composition (and perhaps of comprehension) are arduous, but the labyrinthine product is admirable. Prophetic texts inspired by God constitute still more magnificent mazes, as Jerome (345-ca. 420) knew from his own exegetical experience with baffling (and highly poetic) books of the Bible. Jerome uses and develops the idea of the labyrinth so elegantly in his commentary on Ezekiel that it merits special attention.

The passage in question begins the last book of the commentary, after Jerome has discussed Ezekiel's vision of the reconstruction of the Temple in Jerusalem, a highly complicated building with so many chambers, galleries, winding stairs, and passages that it is a labyrinth in its own right: ${ }^{7}$

What I should have said at the beginning of the Temple of Ezekiel I a m now going to say at the end, reversing the order, mindful of the verse, "Here is the toil of the house and the inextricable wandering" [Aeneid 6.27], concerning which the same poet writes elsewhere, "As once in lofty Crete the labyrinth is said to have had a route woven [textum] of blind walls, a deception which was difficult in a thousand ways, where undetectable and irretraceable wandering while following the signs would trick one" [Aeneid $5.588-591$ ]. So also I, entering the ocean of those scriptures and, so to speak, the labyrinth of the mysteries of God, of whom it is said "He made darkness his covert" [Psalm 17:1 2] and "there are clouds in his circuit"; I do not claim perfect knowledge of truth, but dare offer some indications of

6. Sidonius Apollinaris, Epistulae et carmina, ed. Christian Luetjohann, MGH Auct. antiq., 8, p. $16_{5}$, ll. 88-91.

7. One cannot help wondering whether the eastern tradition that Solomon built a labyrinthine palace or prison (see Batschelet-Massini, pp. 36-39, and Kern, pp. $166_{3-165}$, plates 197-199) is based on the great temple in Jerusalem. 
doctrine to those who wish to know, not by my own powers, but through the mercy of Christ, who himself resolves the tricks and doubtful turns [ambages] for us in our wanderings, guiding our blind footsteps by the Holy Spirit. Following him, we will be able to reach the haven, an explanation of the prophet Ezekiel. ${ }^{8}$

Presumably the labyrinth occurred to Jerome as an introductory topos for several reasons. He may have seen an analogy between ancient labyrinths and the Egyptian complexity of the temple he has just elucidated: the greatest Judaeo-Christian building reminds him of the summit of pagan architecture, and perhaps, as happens later in connection with some cathedral labyrinths, he wishes to suggest that holy biblical architecture rivals and even excels the pagan, a point like Gregory's and Ennodius's but replacing the superiority of God's own handiwork with the superiority of divinely inspired craft. There is also an analogy between the unraveling or explication of the complex ancient labyrinths and the exegesis of the Temple, which is full of symbolic details that create a kind of multicursal labyrinth for the interpreter, who may choose among countless potential meanings for each concrete feature. ${ }^{9}$ For an exegete, the Temple is not merely a house of holy art but also a house of much holier toil than the Cretan labyrinth in the first Virgilian passage Jerome quotes. Perhaps, too, Jerome hopes his elaborate exegesis will decorate Ezekiel's description of the Temple as fittingly as Daedalus's sculpted labyrinth arrayed the temple at Cumae in Virgil.

I have already hinted that Jerome's sophisticated discussion employs the labyrinth not only as an exemplary artifact but also as fruitful if difficult process; like Virgil, both of whose explicit references to the labyrinth he quotes, Jerome deals with both structure and story. The Temple is implicitly a bewildering labyrinth to be solved and finally appreciated, and so too is the text describing it. This text, an "ocean" of possibilities with no clear signposts, is also "a labyrinth of the mysteries of God," an enigmatic prophecy in which a God of darkness, clouds, and circuits has chosen to present himself to humanity. Why God has done this remains unclear-perhaps so that what is wrenched from the text with difficulty will be more appreciated, as theoretical def enses of allegory of ten hold, or perhaps to anticipate the enlightening educational role of Christ-Theseus. In any case, truth is veiled in the labyrinth of mystery,

8. Jerome, Commentariorum in Ezechielem prophetam, $P L, 25,447-449$. I cannot identify the source of Jerome's second biblical quotation.

9. Rather ironically, the Temple, seen by Jerome as the subject of a labyrinthine text to be carefully retraced and explained in his exegesis, becomes a popular source of thematic texts to organize the introduction (accessus) to medieval books: see A. J. Minnis, Medieval Theory of Authorship, pp. 64-66. What was a source of confusion for Jerome becomes a means for later writers to impose order; in short, the same labyrinth betokens both clarity and chaos. 
which Jerome enters like any wanderer in a maze, well aware of possible errores, of the misjudgments and deceptions that may develop from textual ambages. Perhaps the unraveling of Ezekiel is as complex as the Trojan Ride and as fraught with peril as Theseus's entry into the maze. Fortunately, Jerome has a guide: Christ-Theseus, who has trodden the labyrinth and understood it, resolving its ambages for Jerome, who need only follow in his footsteps through Ezekiel's intellectual subtleties to arrive at the transcendence of a valid interpretation. Jerome's exegesis, apparently adopting the fallacy of imitative form, itself becomes a labyrinth: appropriately and gracefully, he reverses the natural order of explication and chooses an artificial order, juxtaposing beginning and end as the twisting path of a labyrinth might do and as Geoffrey of Vinsauf and others later recommend for artistic texts.

Thus, as for Gregory of Nazianzus, God is as mysterious as the labyrinth, and he reveals himself through labyrinthine art-here, a complex temple and a difficult text. If there are tricks and ambages in Ezekiel's labyrinth, however, they are there not to deceive but to enrich and to serve as an occasion for the grace of inspiration. God the labyrinth gave Ezekiel a vision of a temple-labyrinth which Jerome perceives as such; and as Christ unravels the labyrinth of the text for Jerome, so Jerome's interpretation will do for us. ${ }^{10}$ Complex creative artistry begets complex hermeneutic artistry, and both Jerome and his readers require divine assistance lest they err in tracing their respective texts, in making determinate what is cloudy. In describing this metaphorical labyrinth whose dangers are intellectual and whose elaborate circuits may lead to enlightenment, Jerome has followed the advice of his contemporary, Augustine, turning Egyptian gold to better use and Christianizing classical ideas of the structure and myth of the labyrinth. ${ }^{11}$ Complex and artistic texts also are seen as labyrinths, sometimes overly obscure ones with unavailing guidance, in medieval literature.

In these examples, the labyrinth is a sign of magnificent and complex artistry in a structure or text whose apparent confusions may, with the right perspective (or intelligence, or supernatural aid), be revealed as admirable order - the order of an intricate building, of words, of the

10. In medieval manuscripts, commentary is of ten written in the margins, surrounding the commented text on the page. In one sense, commentary is an external tribute to, or decoration of, the enclosed text; in another, it is a textual clue that, followed caref ully, explicates what lies within, carrying the reader to the center of the labyrinth.

11. For Augustine, see On Christian Doctrine 2.40 (para. 6o), p. 75.

Similar associations of the maze with a dif ficult prophetic text and with God as author of that text inform Jerome's Commentary on Zacharias-PL, 25, 1453; see epigraph to chap. 3 . The association of the labyrinthine circles with the spirit and the contexts of Jerome's biblical allusions suggest that again God and his words are the obscure, mysterious labyrinth, which we may interpret only by grace, or perhaps by the contextualizing "thread" of the New Testament. 
cosmos, of God himself. This order is difficult for the artist to achieve and the observer to perceive, but effort or grace may lead to appreciation and understanding of the grand design; these mazes are convertible from chaos to clarity. Labyrinths of artistry imply and celebrate the presence of an architect who may be merely human, as in the classical texts of Chapter 1 or Sidonius's description of the poet's work, but more of ten in Christian texts the greatest praise is reserved for God as ultimate or immediate artifex; his mazes are in summo bono, man's only comparatively excellent. All these labyrinths of art are penetrable and extricable, if only for the elect; but because the process of penetration is so difficult, these mazes have an affinity with the labyrinths of difficult process to be considered later. We will eventually see the medieval progeny of mazes of artistic complexity in cathedrals, in manuscripts, in the maisons de dédale built by aristocrats, and, more or less covertly, in some great medieval poems. The idea of labyrinthine complexity, but generally not the name of labyrinth, will also be manifest in medieval poetic and rhetoric: as we shall see, the labyrinth's connotations in malo grew so dominant that in the Middle Ages the word was seldom used in praise of art even though the thing itself and the name of its architect survive in bono.

\section{- The Labyrinth as a Sign of Inextricability or Impenetrability •}

Many metaphors are based on the impossibility of escaping from the maze (if seen as hazardous) or finding the center (if good lies inside) without special aid, metaphors that see the labyrinth as a dangerous prison or an unfathomable protection for something precious. Unlike artistic mazes, inextricable ones are usually in malo-one would hardly want to escape from something beneficial. Impenetrable labyrinths, on the other hand, may contain unattainable good. Both types are included here because they involve the idea of the maze as perpetual process. Many authors describing inextricable labyrinths write as if from a privileged perspective: they see where the ambiguous circlings lead, and they warn against labyrinthine perils. The very act of writing, then, extends Ariadne's thread to unwary maze-walkers, although these texts may suggest other kinds of guidance through mental or moral errores. If metaphorists see the dangers of these errores and fear their inextricability, they do not invariably conceive of labyrinths as multicursal. Sometimes continuous choice is envisaged, and if so, the very existence of alternatives may be perilous: choice, for many early Christian writers, implies the possibility of straying from the true path, and multiplicity of any sort may have seemed exceptionally dangerous to believers in one God surrounded by pagan pantheons. Sometimes the imposition of a 
clear road to salvation on a dangerous multicursal network is implied, as with Gregory of Nyssa (335-395) invoking Christ-Theseus, Ambrose, and Prudentius. Yet with Gregory Thaumaturgus (213-270) a single path is perilous and the existence of many options advantageous, and some authors seem to have in mind no particular form at all for their mazes. What matters is not so much form as the fact that these mazes, however constructed, are prisons unless guidance is offered. Most inextricability metaphors naturally involve a kind of narrative, describing the confusing and frustrating (or, alternatively, speciously appealing) process of treading a labyrinth whose design and goal are unknown. Plotthe temporal sequence of maze-exploration-is more important than structure or the perception of artifact as artifact, yet this plot is seldom related explicitly to the Cretan myth. Predictably, the shaping role of the architect, stressed in metaphors of artistic complexity, recedes in many examples of the inextricability topos, whereas in others the labyrinth seems to be constructed by the wanderer's own moral and mental failings, which weave an unnecessary maze and complicate what ought to be straightforward: far from being useful processes, these labyrinthine $e r$ rores are veerings off from the right way. In any case, inextricable mazes are to be escaped if at all possible, and although a rescued maze-walker's perceptions may shift so that the maze seen whole looks different from the maze as experienced from within, one generally does not come to see it as good. If anything, these deceptive mazes of harmful digression look better from the inside; an overview reveals horrors that may be hidden from someone just embarking on the twisting path to ruin. These metaphors, then, lead to the realm of morality, and labyrinthine aesthetics are left behind.

Sometimes the minotaur within these mazes is death. A large Roman mosaic on a tomb in Susa, Tunis, reads, "Here enclosed, he loses his life." 12 Christian writers are more optimistic; their labyrinthine prisons of death may be escaped, with the right guidance. For Gregory of Nyssa, the labyrinth is primarily that everlasting death from which only ChristTheseus extricates us:

It is impossible to reach the same goal without following the same path. Those who wander, constrained in a labyrinth, know not the way out; but if they find someone who knows the maze well, they follow him through the complicated and deceptive turns of the building to its end. They would never have escaped had they not followed their guide step by step. Reflect: so is the labyrinth of life inextricable for man if he does not follow the path

12. See Matthews, pp. $4^{8-50,}$ and Kern, pl. 145. The presence of a minotaur in the maze's center clarifies why the image is appropriate and through whose agency the unicursal design is inextricable. 
that led Him who once entered outside. This labyrinth symbolizes the inextricable prison of death, where unhappy mankind was once imprisoned. ${ }^{13}$

Only by choosing the single path that Christ defined within an implicitly multicursal maze-in this case, Gregory goes on to say, the path of baptism - can one escape the maze of death, erring life, and human ignorance. Some such tradition presumably informed medieval carvers who placed mazes on baptismal fonts and, more broadly, the many medieval writers and cathedral-designers who saw Christ-Theseus as harrower of hell and charter of a safe path to salvation. ${ }^{14}$

But one need not be Christian to see life as a maze, disentanglable unless special aid avails, however popular this metaphor was to become in the Middle Ages. Seneca (4 B.C. -65 A.D.) deals with the subject in his forty-fourth moral epistle, evoking a situation and image that may have influenced Boethius in the Consolation of Philosophy. Seneca's addressee, Lucilius, has complained of mistreatment by nature and fortune, but Seneca blames Lucilius's lack of philosophical perspective for his troubles. Lucilius is too entangled in the world; like most men, he has mistaken the means for the end:

While seeking happiness, they are really fleeing from it. For although the sum and substance of the happy life is unalloyed freedom from care $\therefore$ yet men gather together that which causes worry, and, while travelling life's treacherous road, not only have burdens to bear, but even draw burdens to themselves; hence they recede farther and farther from the achievement of that which they seek, and the more effort they expend, the more they hinder themselves and are set back. This is what happens when you hurry through a maze; the faster you go, the worse you are entangled. ${ }^{15}$

The essence of the maze of life is frustration; urgent struggles toward the unseen goal may well lead one away from it, as the winding course of a maze may veer from center to periphery. Vision within the maze is restricted and false goals seem true, with bitter unhappiness and Lucilius's kind of fuzzy thinking the inevitable consequences. Seneca advocates a transcendent alternative: one frees oneself from this labyrinth of futility "simply by distinguishing between good and bad things," by looking "not to the source from which these things come, but to the goal

13. Gregory of Nyssa, La catéchèse de la foi, trans. Annette Maignan (Paris: Desclée de Brouwer, 1978), chap. 35, pp. 90-91.

14. See Francis Bond, Fonts and Font Covers (London: Oxford University Press, 19o8), and plate 15, the Norman font at Saint Martin's, Lewannick, Cornwall. For Gregory, Christ's three days in the labyrinth of hell correspond to triple immersion in baptism.

15. Seneca ad Lucilium epistulae morales, trans. Richard M. Gummere, LCL, 3 vols. (London: William Heinemann, 1925), 1, 286-291. 
towards which they tend." A rational overview, a choice not to follow the traces blindly, frees one from the tyranny of popular opinion and the labyrinth of heedless, hasty life. Fortune may have helped create this maze, but she cannot contain the free philosophical mind, which, like Daedalus, flies above the apparently inextricable mental prisonlabyrinth of life and sees true goals.

For Christian writers, the trammels of mundane mazes are more likely to be woven by sin than by insufficient philosophical detachment. Sometimes original sin is responsible, as with Prosper of Aquitaine (39o-463), whose Carmen de ingratis abounds in labyrinthine language. He describes the moral blindness and mental corruption caused by original sin in a passage whose imagery anticipates the beginning of the Divine Comedy: "The vigor of the mind is blunted and clothed in darkness, and its dull eye cannot bear the lightning of divine light. Thus judgment limps, having fallen into by-ways; in its blind, bandaged efforts there is motion, but there is also wandering [error]. So the will continues, always wanting something to rush towards; and having thus entered into the ambiguities [ambages] of doubtful paths, the will is deceived by the labyrinth."16 The fallen mind is its own maze.

More often, actual sin is the labyrinth, as in Ambrose's exposition of Psalm 1 18:59, "I have thought on my ways and turned my feet unto thy testimonies." Ambrose interprets these lines as an intention "to walk in the paths of your commandments, which will not let me wander [errare], nor my footstep turn aside in devious, twisting ways." He continues by describing those who, ignorant of the way, follow paved routes and thereby avoid "the swervings of error." Others presumptuously "follow some shortcut. Leaving the public road, they of ten run into labyrinths of error and are punished for having left the road, until after much labor they try to find the path they had left." 17 Here, rather atypically, the "path"-presumably the way, the truth, and the light-runs through the labyrinth of trackless countryside but is not part of it. Apparently anything with no clear, direct way out is a sort of maze. Ambrose's almost infinitely multicursal labyrinth is an image of willful sin, which creates its own prison; the contrasting path-perhaps a correct unicursal track laid down in a multicursal wilderness by Christ, scripture, and saints-is right conduct in accordance with received principle. Though not necessarily inextricable, Ambrose's sin-built labyrinth could well become so if

16. $P L, 5^{1,1}, 26$.

17. In Ambrose, Expositio psalmi CXVIII 8.31, CSEL, 62 (Leipzig: G. Freytag, 1913 ), 168. Ambrose's dates are ca. 340-397. Augustine uses a similar image without, however, mentioning the labyrinth explicitly: in matters of interpretation, "it is more useful not to leave the road, lest the habit of deviating force him to take a crossroad or a perverse way": $O n$ Christian Doctrine 1.36 ( para. 41), p. 31 . 
no authoritative guide appears to remedy inexperience, for the great labor its victims expend merely makes them wish for a path; it does not take them any closer to it.

Since labyrinths are woven of error, the maze is of ten used in early Christian and medieval times alike to illustrate the fatal attractions and confusions of heresy and paganism. Thus Hippolytus of Rome (d. 235) claims to have "broken through the labyrinth of the heresies" with the clarity of truth, and Caelius Sedulius (fifth century) chastises pagans, "Daughters of Theseus, why do you wander in labyrinthine caves and frequent the blind thresholds of Daedalus' house?" 18 Here the maze's traditional darkness contributes to its inextricability, echoing the blindness of false believers. Prudentius (348-after 405) draws on the doubleness of the multicursal maze in attacking the folly of those who remain heretics in his own enlightened day, when even pagans like Plato and Aristotle, who "wove [texit] twisted ravings" and were driven by "the double labyrinth and circular error," knew there was only one God.19

Although this is the only time Prudentius mentions the maze explicitly, he habitually associates heresy, sin, and spiritual death with the labyrinthine process of moral choice in life; like Ovid and the Virgil of Aeneid 6 , he may have felt that sufficient density of labyrinthine language establishes the reference adequately. ${ }^{20}$ In the Apotheosis and elsewhere, Prudentius is obsessed with the conflict between unicursal and multicursal options, which mirror the choice between one God and many. Everyone faces a choice between a single path of virtue and infinite paths of vice: "Hard is it to discern the narrow way of salvation amid twisting paths. So many cross-roads meet us, which have been trodden smooth by the misguided straying of the faithless; so many side-roads join together, where tracks intertwine on this hand and that; and if, wandering [errans] at random, a man follows them, leaving the straight path, he will plunge into the snare of a hidden pitfall [of dark reasoning (ambagibus) and intricate arguments]" (Apotheosis praef. 5-24). In this dark wandering, stones are set up to trip us or to guide us on the true path, depending on

18. Hippolytus of Rome, Philosophumena 10.5, trans. F. Legge, 2 vols. (London: SPCK, 1921 ), 2, 149, and Caelius Sedulius, Carmen paschale I.43-44, ed. Nicolaas Scheps (Delft: W. D. Meinema, 1938). Batschelet-Massini (pp. 40-42, 57) also discusses the labyrinth-heresy association commonly found in Christian apologetics.

19. Prudentius, Apotheosis praef. Il. 200-204, in Works, trans. H. J. Thomson, LCL, 2 vols. (Cambridge: Harvard University Press, 1962). Parenthetical ref erences to Prudentius are to this edition.

Prudentius may be the first to associate Aristotle with labyrinths, a topos considered in chap. 7 .

20. Batschelet-Massini also notes Prudentius's habitual use of labyrinthine language and believes that a passage from the Contra Symmachum concerning the road to death was used as an inscription on a labyrinth in the early basilica in Tigzirt, Algeria (pp. 40-41). On the latter point, I remain unconvinced: see Dictionnaire d'archéologie chrétienne et de liturgie, ed. F. Cabrol and H. Leclerq (Paris: Librairie LeTouzey et Ané, 1924- ), s.v. Tigzirt. 
whether we are blind or guided by the torch of faith so that "our steps may be straight" instead of "erring in the darkness" (praef. 40-41). The crossroads are those of heresy; the single path-a true unicursal path through a multicursal maze of error, in essence-is Christ's.

Sometimes the crucial choice of the right path appears simply. In the Hamartigenia (2.789-803) two brothers face a bivium, one road fair and shady, the other narrow and arduous in its ascent, and in such a passage it is hard to see anything truly labyrinthine. But, well aware of life's complexity, Prudentius usually complicates the choice until the image of a labyrinth is inescapably evoked, as in Contra Symmachum (2.843-857), where he argues against allowing the worship of pagan gods. Symmachus had endorsed a multicursal approach to knowledge: "The grand secret of mysterious truth can only be sought out by a multiplicity of ways and widespread tracks; the course which is to search out the hidden God must trace him by diverse ways and tread a hundred paths." Prudentius characteristically believes in a single God and path:

Much going about of ways involves windings and uncertainties and more confused wandering [multa ambago viarum / anfractus dubios habet et perplexius errat]; none but the single way is free from straying [errore], the way where there is no turning aside into a by-road nor hesitation at a number of forks [biviis]. Yet I do not deny that a double path always confronts us and that mortality goes two ways, in uncertainty as to where its ignorance is carrying its steps. The one splits into many branches, but the other is one and single. One follows after God, the other worships a number of deities and has as many offshoots as there are statues in the temples or phantoms flitting about in unsubstantial monstrous shapes.

There are ultimately only two paths, depending on whether one chooses God or gods, and the "simplex via" of God, however much it may twist, is single-a unicursal authorized version superimposed on a deceptive multicursal maze whose paths degenerate into futile branchings and dead ends. In recommending the Ariadne's thread of Christian dogma, Prudentius defines the double maze of belief according to its goal and its guide:

It is a single path, then, on which God is our guide. . . On the manifold way the guide is the devil, who on the left hand splits it into the confusion of a hundred paths. One way he drags bearded philosophers, another way men who are mighty in riches and honor. He tempts them on with the voices of birds, too, and cheats them with soothsaying, incites them with the obscurities [ambage] of a raving old Sibyl, entangles them in astrology. . . . Do you not see how it is but one way, that wanders in many windings under a guide who will not let you go to the Lord of salvation, but shows you the road to death along by-ways. . . Depart ye afar, and enter into your own 
darkness, whither that guide calls you, who goes before you over tangled ways far from the road, in the night of hell! (Contra Sym. 2.882-904)

Divine authority defines a single path to the goal of salvation, safe extrication from the mundane maze; even the devil's multicursal paths are finally single in that they all lead to inextricable hell. For Prudentius, life is a maze or, rather, a pair of mazes: in one, God is guide and reward; in the other, confusion and death abound. Pagans like Plato and Aristotle had no choice but to whirl along the downward windings of the demonic labyrinth, but Christians have supernatural assistance to find the single path to heaven.

Lest we think all multicursal mazes are evil in early Christian writings, Gregory Thaumaturgus views the inextricable labyrinths of pagan thought quite differently. Prudentius accused Symmachus of leading people into multiple mazes on the pretext that only thus would the truth be found. Gregory agrees with Symmachus's method, if not with his polytheism. He praises Origen for making his disciples study many philosophies lest they become imprisoned in one school of thought. For Prudentius, the single path leads to truth; for Origen and Gregory, adhering to a single philosophy creates a tyrannical maze of error holding its victims captive like a swamp that "allows them neither to retrace their steps nor to cross it and effect their safety" or like a dense forest from which a wanderer seeks escape but, "turning in a variety of directions and lighting on various continuous paths within it, he pursues many a course, thinking that by some of them he will surely find his way out: but they only lead him further in, and in no way open up an exit for him inasmuch as they are all only paths within the forest itself."21

Or again, we might take the similitude of a labyrinth, which has but one apparent entrance, so that one suspects nothing artful from the outside, and goes within by the single door that shows itself; and then, after advancing to the farthest interior, and viewing the cunning spectacle, and examining the construction so skillfully contrived, and full of passages, and laid out with unending paths leading inwards and outwards, he decides to go out again, but finds himself unable, and sees his exit completely intercepted by that inner construction which appeared such a triumph of cleverness. But, after all, there is neither any labyrinth so inextricable and intricate, nor any forest so dense and devious, nor any plain or swamp so dif ficult for those to get out of who have once got within it, as is discussion [lógos], at least, as one may meet with it in the case of certain of these philosophers.

21. All quotations are from chaps. 13-15 of Gregory Thaumaturgus, Panegyric on Origen, trans. Alexander Roberts and James Donaldson, in Ante-Nicene Christian Library, vol. 20 (Edinburgh: T. \& T. Clark, 1871), pp. 68-75. 
Gregory's three images are alike in their inextricability, which relates them to fruitless philosophical discussion, and in their lack of any valid goal; Gregory does not necessarily suggest that truth lies within these philosophical mazes but that it may be found through them if one can escape their toils and find a way out. The first two similes remind us of Ambrose's maze, the pathless and therefore infinitely multicursal countryside. ${ }^{22}$ Gregory's true labyrinth, equally though more systematically multicursal, is distinguished from swamp and forest by its artificiality, artistry, and deceptive convertibility whereby aesthetic pleasure turns to confusion with that duality so typical of the maze. Yet although Gregory is well aware of the inextricable dangers that individual multicursal mazes create for the ignorant and single-minded, he, like Origen, sees their value to the enlightened: one learns much from a maze so long as one has a guide like Origen, who led his followers through perilous places "whenever anything tortuous and unsound and delusive came in our way." This Origen accomplished through familiarity with the ground (mazes can be memorized, after all) and because he was "safe in his own altitude," possessor of the privileged perspective that grants a comprehensive vision of both the forest and the trees, the labyrinth as a whole and as a pattern of paths. For Gregory, errands into multicursal mazes are dangerous but necessary; one must experience confusion, trusting one's guide to see one safely out and elucidate the necessary lessons. Labyrinths of words are valuable so long as one has "all freedom to go round the whole circle of knowledge," ultimately assessing the labyrinths of knowledge accurately thanks to an exalted Christian perspective. Multicursal mazes of philosophy, deficient in themselves, are valuable so long as they are not finally inextricable, for Gregory shares Milton's distrust of "fugitive and cloistered virtue." Gregory's sophisticated vision of the maze as essential trial by error has much in common with romances such as the Queste del Saint Graal and with the beneficial mazes of difficult process we will encounter in the next section.

So far inextricable labyrinths have generally represented serious moral or intellectual error. But the image can be a light-hearted cliché as well. Thus Jerome mentions that "a decision which is not doubtful, but clear" can emerge from "labyrinths of entangled dispute," and Sidonius describes a friend's "inextricable labyrinth of complicated business" in which "he does not know what to reject or choose." 23 The ease and grace

22. In Arabic, a similar logic seems to prevail: the words tih, taiha, and mataha (all related to taha $i$, to get lost, to perish, to conf use) all mean both labyrinth and desert: see Hans Wehr, A Dictionary of Modern Written Arabic, ed. J. Milton Cowan (Wiesbaden: Otto Harrassowitz, 1961). I am grateful to Jane Dammen McAuliffe for this reference.

23. Jerome, Contra Iohannem 14, PL, 23, 382; Sidonius, Epistolae et carmina, MGH Auct. antiq. 8, p. 28. 
of such allusions indicate how familiar the labyrinth and its attributes were in the early Christian period, and although in these examples labyrinths are bothersome, they are neither very bad nor particularly immoral.

Labyrinths of impenetrability are also founded on the idea of the maze as a place in which one cannot get where one wants to go or understand what must be understood; this labyrinthine nuance is reflected in one possible meaning of the common medieval etymology "labor intus," "difficulty going in." Since one cannot get in, presumably to reach a desired goal, the impenetrable maze carries fewer negative connotations than does the inextricable labyrinth. The function of this impenetrability, as in the Cretan myth, is usually to protect something inside: in the passage from Aelian, the ants are protected; for Gregory of Nazianzus and Jerome, God's mystery is veiled by the cosmic or textual maze. According to Vegetius, the Roman legions had labyrinthine impenetrability in mind when they took the Minotaur as a heraldic sign: "Just as the Minotaur was described as hidden in the deepest, most secret labyrinth, so too the counsel of the leader ought always to be hidden." 24 The labyrinth that may have figured on the robes of Roman emperors carries a similar message: a medieval manuscript claims that imperial robes were decorated with "a labyrinth made of gold and pearls, in which is found a minotaur made of emerald holding its finger to its mouth, for just as no one might examine the labyrinth, so no one ought to betray the secrets of the monarch." 25

Perhaps it is also in this context that one should take Prudentius's description of the Tiburtine catacombs in his praise of Hippolytus of Rome. Although Prudentius does not use the word labyrinthus, it seems to have been in his mind, suggested perhaps by the name and fate of this saintly namesake of Theseus's ill-fated son (Saint Hippolytus too was martyred by wild horses) and also by the physical nature of the catacombs, those caves into whose "hidden depths a downward path shows the way by turning, winding steps," the whole a "fabric of narrow halls running back [texant] on either hand in darksome galleries," a fit "place of concealment" for the body of a man who lapsed into heresy

24. Vegetius, Epitoma rei militaris 3.6, ed. Carl Lang (Leipzig: B. G. Teubner, 1885). See also Festus, De verborum significatione, s.v. minotauri. This tradition has intriguing implications for Chaucer's Knight's Tale, where Theseus's emblem is the Minotaur.

25. See A. F. Ozanam, Documents inédits pour servir à l'histoire littéraire de l'Italie (Paris: Jacques Le Coff re, 1850), which transcribes the Graphia aureae urbis romanae found in Bibl. Laur. Pluteus 89, inf er., cod. 41, a manuscript (also containing a Vegetius text) dated by A. M. Bandini (Catalogus codicum latinorum bibliotecae mediceae laurentianae, [Florence: Petrus Leopoldi, 1774-77], III.408) as from the thirteenth-fourteenth centuries. Ozanam suggests the Graphia must originally have been written between the sixth and eighth centuries (p. 91). Kern dates the manuscript ca. 1030 and asserts that it enjoyed great influence during the Italian Middle Ages (p. 291). 
only to reform and call "people away from the path on the left and [bid] them follow where the way on the right calls, presenting himself as their guide on the straight road and rejecting all windings, the very man who was formerly the cause of their going astray." 26 Thus the deceptive labyrinth of heresy is appropriately converted to the protective labyrinth of a sacred tomb. 27

A fusion of labyrinthine inextricability and impenetrability also occurs in the De civitate Dei of Prudentius's contemporary, Augustine (354430). ${ }^{28}$ Like Prudentius, Augustine associated pagan philosophy with labyrinthine thought; and like Prudentius, he of ten used language that creates the mental image of a maze without explicitly mentioning the word. Refuting the neo-Platonic concept of recurring cycles, within which there can be no "new thing," and arguing that the creation of man and the sacrifice of Christ are just such "new things" that "shatter these revolving circles" $(12.17 / 18)$, he contrasts "the straight path of sound doctrine" with the "circuitous paths discovered by deceiving and deceived sages" (12.13/14). Platonists and their ilk are "entangled in these circles," and "they find neither entrance nor egress . . . since they cannot penetrate the inscrutable wisdom of God" $(12.14 / 15)$. Hence, "the wicked walk in a circle: not because their life is to recur by means of these circles, which these philosophers imagine, but because the path in which their false doctrine now runs is circuitous" (12.13/14). The image inescapably conjured up by this language is a circular labyrinth at whose center sits a God unsearchable in his totality by the human mind, least of all the pagan mind. The wicked see themselves as trapped in infinite circles, a temporal labyrinth with no goal, no ending that does not immediately transform itself into another beginning of the same ineluctable process. For Augustine, this pagan labyrinth of time is a fiction: Christ is the "straight path" (12.20/2 1) who leads believers to truth and to the God so inaccessible to pagans and who frees his followers from the illusion of endless recurrence. The real labyrinth in which pagan philosophers find themselves, for Augustine, is their way of mental error, as inescapable as the endless temporal circles they imagine. The wicked thus condemn

26. Prudentius, Peristephanon 11 , in Works, 2, pp. 307, 315, 317 (ll. $35^{-38,154-156,163-}$ 164).

27. The labyrinth in San Reparatus, Orléansville, Algeria, could also be a protective device. The fourth-century pavement, near the north entry to the church, shows a square unicursal labyrinth whose center is another labyrinth of sorts, made of a grid of letters: traced from the center in any direction, the letters read "sancta ecclesia." Perhaps the center represents the mysteries of the church, protected from the dangers of the world by a labyrinth of secrecy. See Matthews, p. 54 and fig. 42; Santarcangeli, pp. 285-288; Kern, figs. 98-99. The labyrinth could also signify the world, to which the Church forms a stable center or guiding clue.

28. Augustine, De civitate Dei $12.13^{1} 4^{-20} / 21$; I follow Oates's translation in Basic Writings of Saint Augustine and, for the Latin, Bernard Dombart and Alphonsus Kalb, eds., CCSL, 48 (Turnholt: Brepols, 1955); English and Latin chapter numbers differ by one. 
themselves to futile circles that are inextricable (short of conversion) and that render God a totally impenetrable mystery. Dante's Inferno provides a not dissimilar vision of the fate of the damned.

For Augustine, the labyrinth of pagan thought thus spawns a vision of a labyrinth that is (patterned) infinity, rather like Gregory Thaumaturgus's potentially endless philosophical labyrinth. In Simplicius's important commentary on Aristotle's Physics, the labyrinth explicitly becomes an endless figure signifying infinity. Normally labyrinths have ends (a goal, a center, or an exit), but these features are irrelevant for Simplicius. Although a labyrinth is spatial and "theoretically able to be traversed," its peculiar construction makes it "practically impossible to traverse" and therefore infinite. ${ }^{29}$ So neutral and logical a discussion of the labyrinth's inextricability is extremely rare; although the idea of the labyrinth's infinity is seldom developed, it may be inherent in identifications of the labyrinth with the infinite and impenetrable mystery of God.

Most inextricable labyrinths carry heavy moral freight. Their structural errores, whether traps laid by devils and heretics or confusions created by maze-walkers themselves, are inescapable unless special aid is granted. Prisons whose darkness and obscurity correspond to the moral or intellectual blindness of their inhabitants, they afford no sight of a goal, no sense of pattern, and they lead almost inevitably to chaos, death, and damnation. Thus they become useful signs for everything constricting and imprisoning (death, life, sin, heresy, pagan philosophy). Whenever the labyrinth is used in malo, its primary characteristic is likely to be its inextricability. Yet, in still another assertion of labyrinthine duality, the very ambages that make a labyrinth so inextricable may also render it impenetrable, a useful sign for everything protecting and enfolding a precious mystery. The labyrinth's negative connotations predominate, however, and the vast majority of medieval labyrinth metaphors link inextricability and evil. Representing death, sin, heresy, and hell so commonly and effectively in classical and early Christian times, the maze remains a favored symbol in malo.

\section{- The Labyrinth as a Sign of Difficult Process •}

If the ambages of inextricable mazes entrap the wanderer and the windings of impenetrable labyrinths deny access to a wished-for goal, the difficult processes of this final category are, at least in theory, benevolently teleological: these ambages are educational, leading the mazewalker to a conclusion-even a transcendence-greatly to be desired. A

29. See Aristotle, Physics 3.4, trans. Philip H. Wicksteed and Francis M. Cornford, 2 vols. (Cambridge: Harvard University Press, 1970), and Simplicius, In Aristotelis physicorum commentaria, ed. Hermann Diels (Berlin: G. Reimer, 1882), p. 470. 
circuitous route may be the only effective way to reach a goal. Ignorant almost by definition, the wanderer will be baffled and confused while immersed in the processes of intellectual mazes, but the labyrinth is designed to lead to enlightenment; it is a mental exercise, a challenge to be met if there is to be any progress. Because these labyrinths are intended to teach, the writer-architect may even conduct a guided tour of his artistic product by participating in the action, which is frequently a dialogue, dialectic, or debate. His certainty of the pattern contrasts with the wanderer's ignorance and bewilderment, and the conf usion/artistry duality of the maze may be prominent thanks to the coexistence of two perspectives within the text. Usually these mazes are labyrinths of words and concepts carefully strung together, not the physical structures of complex artistry or the moral quandaries of inextricable labyrinths, although mazes of difficult process have much in common with textual mazes. There is, however, a slight difference in emphasis: in many mazes of difficult process we experience what it is like to be inside an artistically wrought verbal labyrinth before the moment of enlightenment that permits appreciation of the whole structure. These mazes may be unicursal, multicursal, or perhaps both at once: they may include abundant alternatives-sometimes too many-and there may be dead ends or circular reasoning that gets nowhere; but when a knowledgeable guide is present, there will also be a sense of relentless if circuitous progress. These mazes, then, are intended to function in bono, although they may fail to achieve their ends if the architect has overcomplicated his creation or if the neophyte wanderer is not up to the challenge.

The labyrinth as a metaphor for learning seems to be related to concepts of perception and thought as intrinsically labyrinthine processesinvoluted, circuitous, doubling back at blind alleys or enforced turns, working by trial and error or by successive approximation. The roots of the metaphorical uses of the labyrinth in this context may lie in the complex linear functioning of perception and the brain, as outlined by the faculty psychology that dominated classical and medieval epistemology. ${ }^{30}$ The explicit description of perception as a labyrinth is rare, though it does occur. Both Galen and the Naassene heretics thought that hearing was a labyrinth. ${ }^{31}$ And Prosper of Aquitaine's description of the mental incapacities produced by original sin, quoted earlier, suggests

3o. For a brief discussion of faculty psychology, some fascinating illustrations indicating the linearity of perception, and a bibliography, see Edwin Clarke and Kenneth Dewhurst, An Illustrated History of Brain Function (Oxford: Sandford Publications, 1972), chaps. 2-5. See also Edwin Clarke and C. D. O'Malley, The Human Brain and Spinal Cord: A Historical Study Illustrated by Writings from Antiquity to the Twentieth Century (Berkeley: University of Calif ornia Press, 1968).

3i. Galen, De usu partium 8.6, ed. Georg Helmreich, vol. 1 (Leipzig: B. G. Teubner, 1907), 468, and Hippolytus of Rome, Philosophumena $5.11(1,143)$. The inner ear itself is not generally described as a labyrinth until the Renaissance. 
84 . The Labyrinth in the Classical and Early Christian Periods

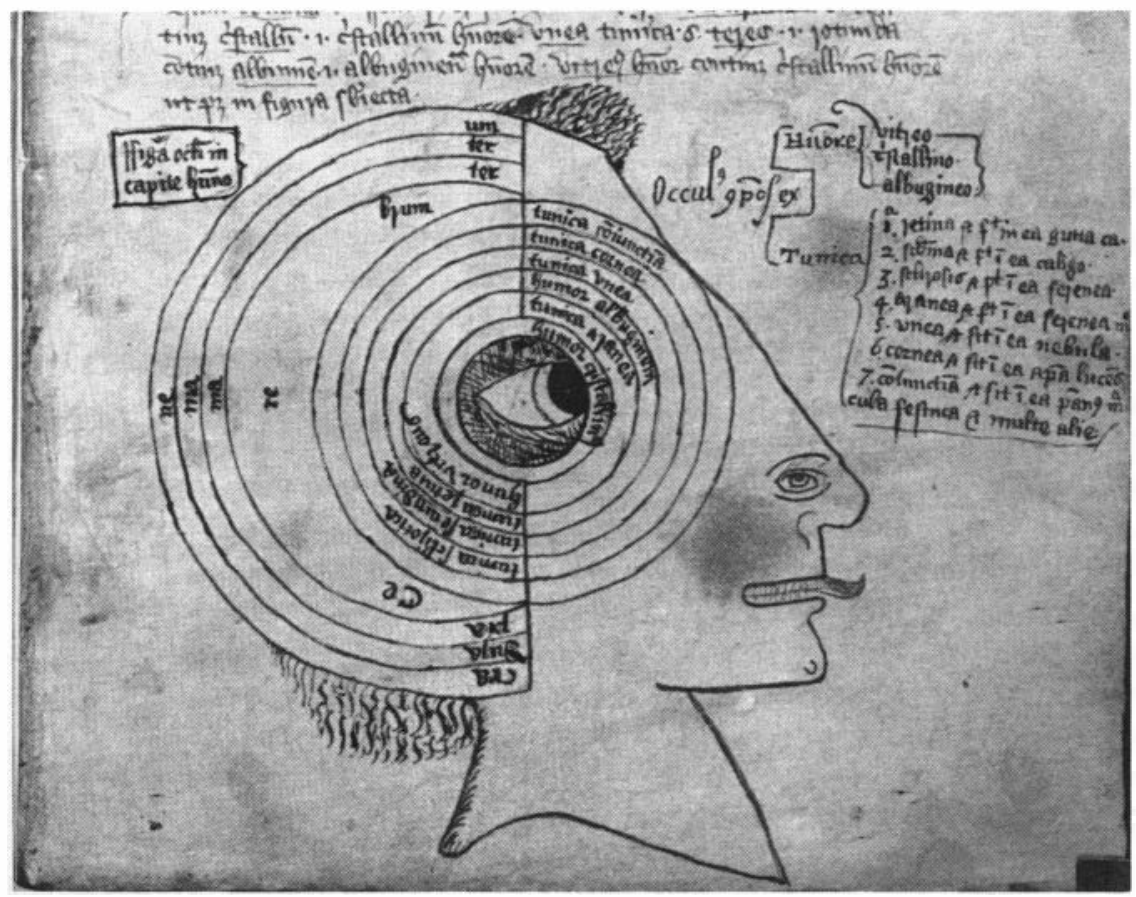

7. Eye-brain diagram dating from 1350-1400 but probably derived from a treatise by Magister Zacharias of Salerno and Constantinople (twelf th century). London, British Library MS. Sloane 981, fol. 68r. By permission of the British Library.

that fallen man exists in a perceptual maze. The brain itself has a labyrinthine structure of convolutions or gyri, their very complications reflecting the high level of human intelligence according to Erasistratus (third century B.c.). There are also the brain's "chambers" of imagination, reason, and memory, crammed with images and surrounded by passages like the courts of the Egyptian maze; the finely branching network of veins in the pia mater, described in 1615 as "a mazey laberynth"; and the rete mirabile, the wondrous net described by Galen, Rufus of Ephesus, and others as a complex interlace in which the animal spirits essential to accurate perception are manufactured. ${ }^{32}$ Diagrams of eye and brain are more vaguely labyrinthine, featuring concentric circles with divisions and links between them (see plates 7,8 ). I have found no incontrovertible early European evidence that the brain was viewed ex-

32. See Clarke and Dewhurst, chaps. 2, 3, 5; Helkiah Crooke, Microcosmographie (London: W. Jaggard, 1615), p. 465; Galen, De usu partium 9.4. Throughout the Middle Ages, the rete mirabile, a feature of pig and ox brains, was erroneously assumed to exist in the human brain. 


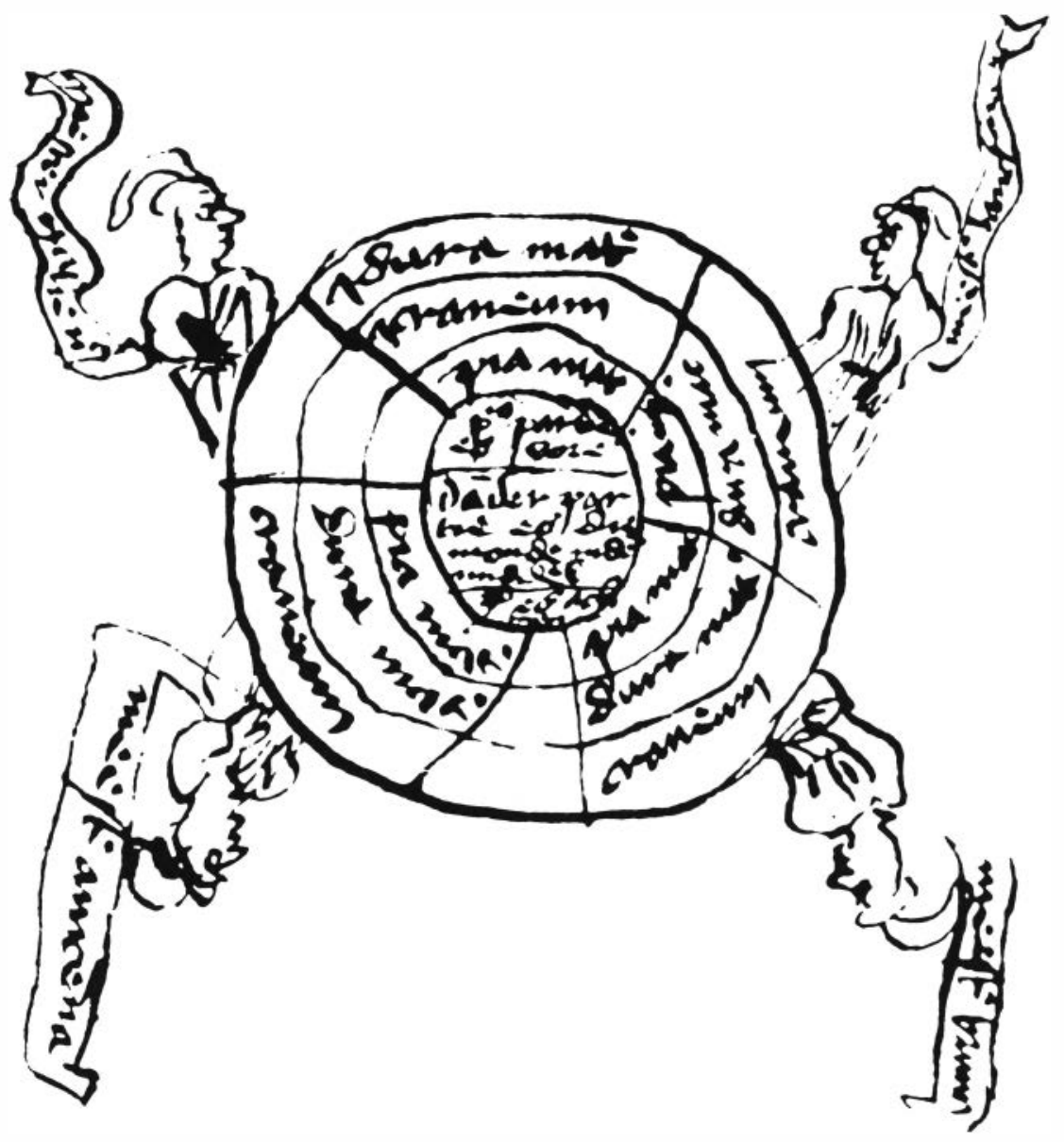

8. Vaguely labyrinthine diagram of the brain, from Jehan Yperman's Cyrurgie (1328). Ghent, University Library MS. 1273, fol. 3v. By permission.

plicitly as a maze, but there may have been such a tradition in India, and certainly the similarity might have been apparent to anyone who had ever seen a brain. ${ }^{33}$

In any case, metaphorical labyrinths involving the idea of difficult process appear frequently and explicitly in the context of mental activities, particularly the processes of teaching, learning, and understanding. Sometimes a labyrinth of difficult process defeats its own instructional aim, either through the artist's failure to shape it well enough or through the maze-walker's inability to perceive its order because he can- 
not choose among too many alternatives and is disoriented by too many data. Thus a character in Macrobius's Saturnalia (ca. 400 A.D.) reports that the "rounded phrases" and "volubility" of "a glib Greek" have rendered him "unable to cope with this labyrinth of words." And Cassiodorus (sixth century) is swamped by a "labyrinth of explanations." Hence the labyrinth becomes an appropriate sign of general mental perplexity: Lucian (second century) refers to "inextricable and labyrinthine questions," and Ennodius, embroiled in a knotty procedural issue, asks for help to "overcome the sinuous twist of this labyrinth." Such usages may well have contributed to the common medieval notion that any text explicitly called a labyrinth is bad, or at least ineffective, art. But the labyrinth also promises the joys of mastering almost insoluble difficulty: Sidonius eulogizes a philosopher who "thought it the height of pleasure if by chance the treasures of his knowledge were aired when some labyrinthine puzzle arose," and Marius Mercator (fourth century) advocates marking manuscript margins with a labyrinth to indicate a textual passage repaying careful study, a practice C. Du Cange attributes to Isidore of Seville $(560-636) .{ }^{34} \mathrm{It}$ is in this sense that labyrinthine art, even if it is not called by that name, is so of ten judged excellent in later periods.

In teaching and learning, the subjective problems created by a labyrinthine experience are particularly important. If a learned doctor of the church like Jerome can penetrate Ezekiel's labyrinth of prophecy only with divine aid, how much more sensitive are the problems of leading the ignorant through material that will seem intolerably labyrinthine until they have achieved some wisdom! We have seen Gregory Thaumaturgus's praise of Origen for doing just that, as well as Gregory of Nazianzus's ironic invitation to try to comprehend the grand obscurity of the cosmic maze by carefully following one track or another. Without using the word "labyrinth," but with some density of language usually associated with mazes, he worries elsewhere in the Second Theological Oration that his exceptionally ornate discussion is "too subtle" for the common ear, that his argument has been too "tortuous and enigmatic." He knows that difficulty is not bad in itself: "What is acquired with difficulty is usually preserved the better," a common topos. Gregory

34. Macrobius, Saturnalia 7.5.1, trans. Percival Vaughan Davies (New York: Columbia University Press, 1969); Cassiodorus, Historia Tripartita 5.37, in PL, 69, 1017; Lucian, cited in Meursius, Crete, p. 69; Ennodius, Libellus pro Synodo, ed. F. Vogel, MGH Auct. antiq., 7, 56 ; Sidonius, Epistolae et carmina, MGH Auct. antiq., 8, p. 62; Marius Mercator, Concilium universale ephesenum, in Acta conciliorum oecumenicorum, ed. E. Schwartz, tom. 1, vol. 1, pt. 1 (Berlin and Leipzig: Walter de Gruyter, 1924-26), p. 81; C. Du Cange, Glossarium mediae et infimae latinitatis (Paris: Librairie des Sciences et des Arts, 1938), s.v. labyrinthus. Although Isidore describes the classical labyrinths $(15 \cdot 2.36)$, the edited text does not recommend the maze as a marker of difficulty: see Etymologiae 1.21.10, where the cryphia $(\odot)$ is suggested for difficulty or insolubility. Perhaps in some manuscripts the mark was elaborated into a labyrinth. 
finds our nature so imperfect that the divine is necessarily obscure to us, for God "makes the darkness his covert" (Psalm 1 7:1 2, a passage quoted also by Jerome). In fact, "the more perfect our discussion of God, the more difficult it is of access. . . Every obstacle, no matter how small, halts discussion in its course ... as when one pulls the reins of a horse and makes it turn with the unexpected shock." 35 One cannot prove that Gregory had the maze metaphor in mind, but his epistemology sees the attempt to acquire knowledge of God as a necessarily labyrinthine process: confusing, difficult of access, full of hidden twists and turns. The safest and surest course is to rise above the labyrinths of earthly creation and human reasonings to glimpse God the architect at the center of all things. ${ }^{36}$

The labyrinthine process of learning is particularly marked in the dialectical method, so common in classical and medieval education. One may be led down exceedingly circuitous and of ten branching paths, quite at the mercy of the word-architect who limits the options. Predictably, Plato (428-348 B.c.) was well aware of the pitfalls of his chosen method, especially when used badly. The Euthydemus is a lighthearted discourse involving Socrates and two verbal tricksters who abuse wordplay to turn every question inside out many times over. The results are predictable: their grotesque argument "seemed like falling into a labyrinth; we thought we were at the finish, but our way bent round and we found ourselves as it were back at the beginning, and just as far from that which we were seeking at first" (Euthydemus 291B). The persistent and senseless ambiguity of the questions and answers make the investigation fail, bending back and forth interminably as in a maze without a center. The dialectical method permits such fruitless circuitousness, though it does not, from Plato's point of view, necessitate it. Socrates, Daedalian offspring that he is, clearly relishes the absurdities of the peculiar procedures of this dialogue, which may anticipate what medieval writers have in mind when they decry the inextricability of "Aristotle's labyrinth." Badly used, dialectic is a labyrinth of difficult process going nowhere.

But for all his ironic humility, Socrates is sophisticated in the art of argument; he is wise enough to see the pattern of the labyrinth created by buffoons pretending to instruct him. The situation is quite different when a wise man seeks to instruct buffoons. Thus, in a passage we will return to in Chapter 9, Philosophy almost loses her obtuse pupil Boethius when she creates a kind of logical labyrinth with her difficult circular argument proving that evil does not exist. Boethius, eager to learn but querulous in temper, objects: "'You are playing with me,' I said,

35. Gregory of Nazianzus, Oration 28.11, 12, 21.

36. See Miller, Measures of Wisdom, pp. $35^{2-361 .}$ 
'by weaving a labyrinthine argument from which I cannot escape [inextricabilem labyrinthum texens]. You seem to begin where you ended and to end where you began. Are you perhaps making a marvelous circle of the divine simplicity?" 37 Such indeed is Philosophy's tactic, and after retracing the path of the argument and hearing Philosophy's explanation of her method, Boethius is finally able to fly with philosophical wings from confusion to clarity, from immersion in this particular labyrinth to the elevated perspective that bestows comprehension. In so doing, he carries his still less sophisticated audience (most of his readers) along with him. Labyrinths, especially when recognized as such, have pedagogical uses: they institutionalize repetition and explication.

Augustine too was keenly aware of the labyrinthine nature of learning. He openly discusses the dangers of mental labyrinths in the early work Contra academicos (386-87). He and his friend Alypius are debating in the presence of the youths Licentius and Trygetius, and Augustine worries lest the dialogue be too intricate for boys "unable to discriminate acute and subtle arguments"; the youngsters may not realize that Alypius is "not extricating [him]self by complicating matters"- that difficult argument is not necessarily correct reasoning. After a break, Augustine is not surprised to find Licentius scribbling poetry as respite from the rigors of argument; one cannot remain in labyrinths indefinitely. Af raid that the debate has overtaxed the boy, Augustine says, "While I wish to invite both of you back to the arena of those intellectual exercises that impart refinement to the mind, I fear lest it become a labyrinth for both of you."38 A good teacher must always beware of creating exhausting labyrinths for the unsophisticated, even though identical arguments may seem labyrinths of artistry to the learned from their wiser perspective; labyrinthine arguments are relative in impact like the maze itself, and the skilled teacher considers this relativity in gauging the receptive capacities of his students. We will see later how concerned medieval rhetoricians and preachers were with this problem.

In a dialogue on the role of the teacher (De magistro, ca. 389), Augustine delineates a labyrinthine theory of education, and although he (unlike his translators) never mentions the labyrinth explicitly, the process he describes explains so neatly the usefulness of a circuitous, confusing, labyrinthine dialectical method that it is worth summarizing briefly. After some potentially confusing discussion of sign theory, Augustine's

37. Boethius, The Consolation of Philosophy (523-524), 3 pr. 12, p. 72. For the Latin, see Boethii Philosophiae consolatio, ed. Ludwig Bieler, CCSL, 94 (Turnholt: Brepols, 1957). Additional examples of Boethius's concept of labyrinthine argument are noted in chap. 9 .

38. Contra acad. 3.6, 7, trans. Denis J. Kavanagh in The Writings of St. Augustine (New York: Cima Publishing, 1948). For the Latin text, I use Oeuvres de St. Augustin, 1st ser., vol. 4, ed. R. Jolivet (Paris: Desclée de Brouwer, 1939). Earlier in the dialogue, Augustine has referred to Daedalus (3.3). 
son Adeodatus has lost track of the argument. This does not surprise his father, who knows the discussion is "entangled [implicatum]," so he begins again. ${ }^{39}$ When Adeodatus is again confused, Augustine admits there have been "so many circumlocutions [ambagibus]" (p. 378/180) that it is hard for Adeodatus to know where he is, let alone where the discussion is going. Later still, Augustine reviews the "great circling [circuitus]" they have undergone, summarizing the points they have determined so far and raising another question: Is Adeodatus sure of all these concepts now? The boy answers, "I wish indeed to have arrived at certainty after such great debate and complications [ambagibus], but your question disturbs me. . . The problem is such a labyrinth [implicatio] that I am not able to explore it thoroughly or to answer with assurance" (p. 386/19o). And so Augustine retraces the chain of reasoning to ensure that Adeodatus will understand.

What Augustine is teaching Adeodatus is that the teacher does not instruct his student, but rather, by repeated questioning, he reminds the pupil of what the pupil already knows. Often in this process the pupil does not know an answer because he cannot see the issues whole; thus "he is advised to do it part by part when he is questioned by one step after another about those very parts of which the whole consists, which he is unable to grasp in its entirety." The pupil is led circuitously and repeatedly over the same ground, just as in a labyrinth, so that he learns it well and comes to see the whole pattern, not just its fragments, and "by means of questions put in such a way [he] is able to teach himself" ( $p$. 391/198). This kind of inward self-instruction, guided by a wise and sensitive teacher, may well be tortuous and time-consuming, but it is the only effective way to teach-or rather, for Augustine, to remind the pupil of what he already knows. Of course, the process of learning is labyrinthine whether or not prior knowledge is involved: one moves in circles, forward and back, seeming to recede but in fact ever approaching by successive approximation the knowledge that is the goal. And this knowledge could not be reached so effectively by a direct route, a shortcut, for the process itself determines whether the product will be understood. The psychology of learning and the labyrinthine dialectical method are, for Augustine, perfectly matched: in the hands of a wise teacher, dialectic is the guiding clue that carries the mind through all the slow, essential, indirect paths to knowledge. ${ }^{40}$ The duality of the maze again is

39. For the English, I follow Concerning the Teacher, trans. G. C. Leckie, in Oates, Basic Writings (here, chap. 5, p. 372); for the Latin, CCSL, 29 (Turnholt: Brepols, 197o), pp. 156203; here, p. 171. Further references will be given parenthetically.

40. For an interesting parallel discussion of the text, see Seth Lerer, Boethius and Dialogue: Literary Method in "The Consolation of Philosophy" (Princeton: Princeton University Press, 1985), pp. 51-56. Although Lerer does not overtly see the dialogue as embodying labyrinthine principles, he notes not only the importance of ambages and circuitous argu- 
relative: for the ignorant it is simply confusion, but for those able to learn it is confusion leading to a perception of order and meaning. What was a labyrinth to Licentius is elegant reasoning to Augustine. This theory of learning will be very important when we come to discuss the labyrinthine aesthetic of later medieval literature and the reception of complicated texts.

As to whether these instructional labyrinths are unicursal or multicursal, the answer is that they are really both at once, rather like the moral mazes of Prudentius. Intrinsically, there are countless pathsinnumerable ways to approach the goal of specific knowledge. At the same time, the path selected by the teacher from so many possibilities may seem unicursal: he knows where he is going and how to get there. But to the pupil, the same mental journey may appear multicursal, with one series of questions and choices superceded by another series, leading to an as yet unimaginable goal. Perhaps the convertibility of the maze manifests itself most obviously in intellectual labyrinths.

In this chapter we have seen how the labyrinth's essential features suggest its metaphorical significance from the time of Plato through the sixth century A.D. The labyrinth as a sign of complex artistry most commonly refers to admirable artifacts, whether the work of God, man, or animal; these are incontrovertibly labyrinths in bono, and although their magnificence depends on initially baffling complexity, we are most aware of the inherent order controlling multiplicity. Inextricable mazes, on the other hand, emphasize the perpetual imprisonment that multiplicity and complication can enforce, and these labyrinths tend to operate in malo. Impenetrable labyrinths frustrate maze-walkers because the

ment but also the dialogue's "two contradictory movements," "one which sees dialogue as a linear progress towards truth; the other which sees it as a circuitous set of restatements whose goal is unclear" (p. 52). These two movements-which I would see as circling about a goal unknown to the student or reader, which is at the same time linear progress toward that same goal as perceived by the teacher-precisely define the quality of motion experienced in a circular maze and suggest the effect of divergent points of view.

See also Lerer's discussion of Augustine's Soliloquia (pp. $4^{6}-5^{1}$ ), in which Augustine casts himself as student and progresses from craving a shortcut to contentedly following the winding course of argument.

The labyrinth of learning implicit in Augustine's discussion resembles the "affective process" hinted at by Aegidius Romanus and developed by Judson Boyce Allen in respect to certain medieval texts: when "the literal ordering of a text's material corresponds exactly to the order of that mental process whereby that material was invented [or discovered, or structured] and made significant," then "its meaning must arise out of the dialectic motion through its parts that is the experience of its characters" (The Ethical Poetic of the Later Middle Ages: A Decorum of Convenient Distinction [Toronto: University of Toronto Press, 1982], pp. 92-93). In other words, it is only by experiencing the process of a text as it is written, with all its involutions and false turnings, that its meaning can be grasped; form and meaning are inseparable, and the modus agendi (mode of literary treatment) is precisely the necessary modus docendi (method of instruction). 
desirable goal cannot be attained; these mazes have something in common with failed labyrinths of difficult process, where knowledge that ought to be achieved remains distant. Ideally, if artist and maze-walker have done their respective work properly, mazes of difficult process lead to valuable goals: the transcendence of labyrinthine confusion, highlighted here as in the mazes of inextricability, and the appreciation of labyrinthine artistry. With these backgrounds in mind, we are ready to pursue the further metamorphoses of the labyrinth in the Middle Ages. 
